\title{
Gesäuse National Park - a rugged wilderness
}

\author{
Petra Sterl \& Daniel Kreiner
}

\section{Abstract}

200 years ago, the natural beauty of the Gesäuse region, the contrast between the river Enns and the sheer rock faces of Gesäuse mountains with their diverse habitats and species, already attracted researchers and mountaineers to this area in the heart of Austria. As early as 1958, the Gesäuse and the valley of the river Enns leading out of it were designated as the first conservation area in Styria. Persisting plans for hydroelectric power generation on the Enns eventually led to the creation of a national park in 2002.
Profile

National Park

Gesäuse

Mountain range

Alps

Country

Austria

\section{Introduction}

Currently there are six national parks in Austria (Figure 1), which are recognized by the IUCN as Cat. II national parks. Covering an area of $2350 \mathrm{~km}^{2}$, they make up ca. $3 \%$ of the Austrian territory (www.nationalparksaustria.at) and include some of the ecologically most valuable regions. They are organized under the umbrella of Nationalparks Austria to leverage synergies and to ensure consistent presentation to the general public. The directors of the national parks coordinate and initiate joint activities in cooperation with the Federal Ministry of Agriculture, Forestry, Environment and Water Management and the respective federal provinces.

National parks across the world aim to protect areas of outstanding natural beauty, rich diversity of plants and animals, rare or endangered species and special natural phenomena. The label is designed to prevent technical development and economic exploitation and to safeguard natural dynamics. Humans are invited to participate as quiet observers.

As internationally recognized IUCN Cat. II protected areas, all national parks in Austria are committed to four basic tasks:

- conservation and protection of biodiversity;

- recreation and nature experience;

- education about nature and the environment; research.

\section{The youngest national park in Austria}

The Gesäuse NP was established on 26 October 2002 and internationally recognized in 2003 by the IUCN as Cat. II protected area (national park). Large areas of the national park are also part of the Natura 2000 network in the sense of the EU Fauna Flora Habitat and Birds Directives. With 11000 ha, it is the third-largest

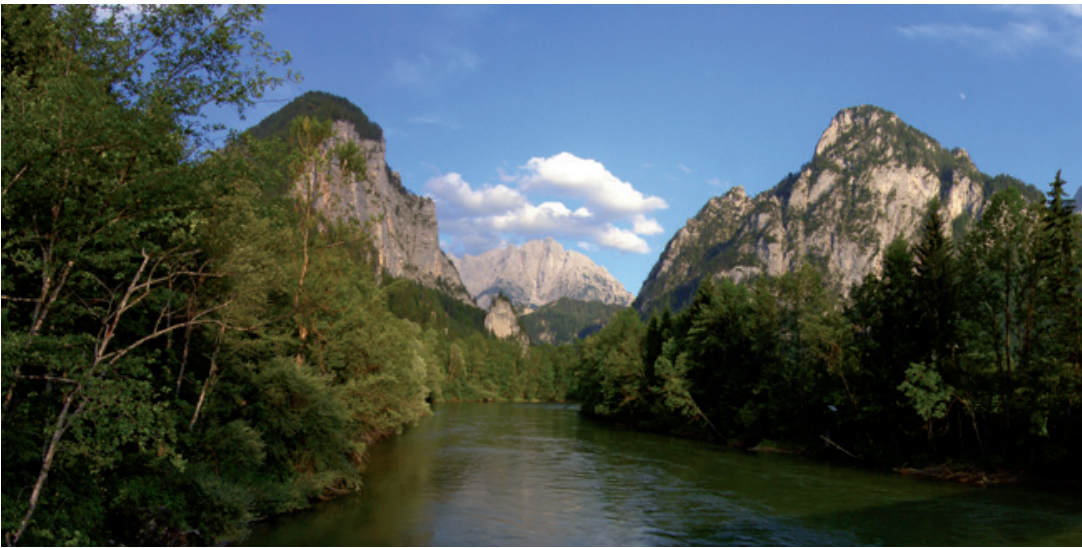

The landmark of the Gesäuse mountains: the Gesäuse entrance with the Enns ravine against the northern cliffs of the Hochtor range. (C) A. Hollinger

national park in Austria. It is situated in the Ennstal Alps in the province of Styria, which are part of the Northern Limestone Alps and includes essentially the two mountain ranges of Buchstein and Hochtor. In the north it borders on the Eisenwurzen Nature Park and is only ten kilometres away from Kalkalpen NP in

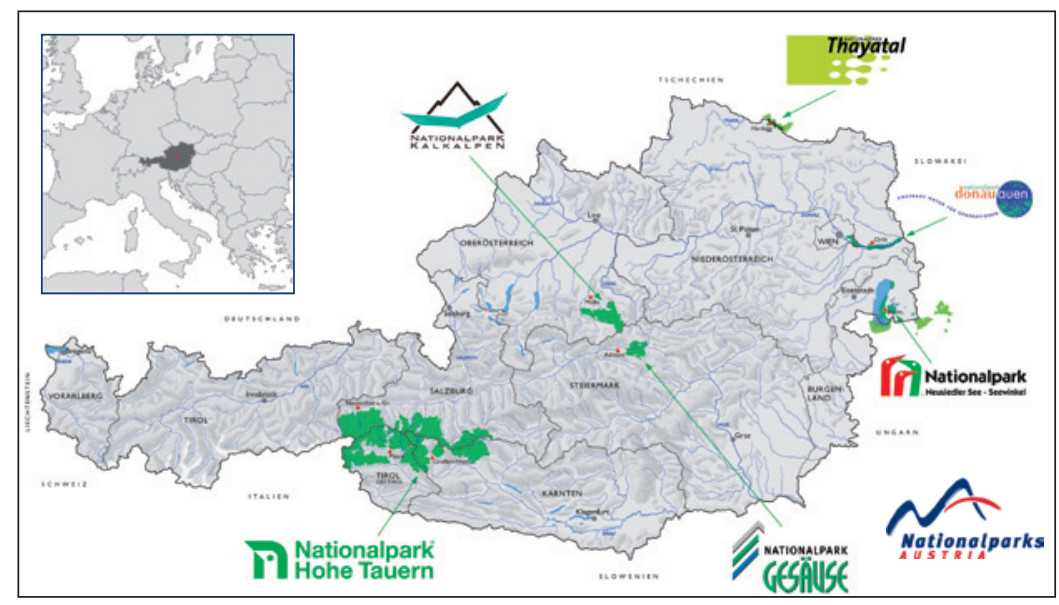

Figure 1 - National parks in Austria. (C) Nationalparks Austria 


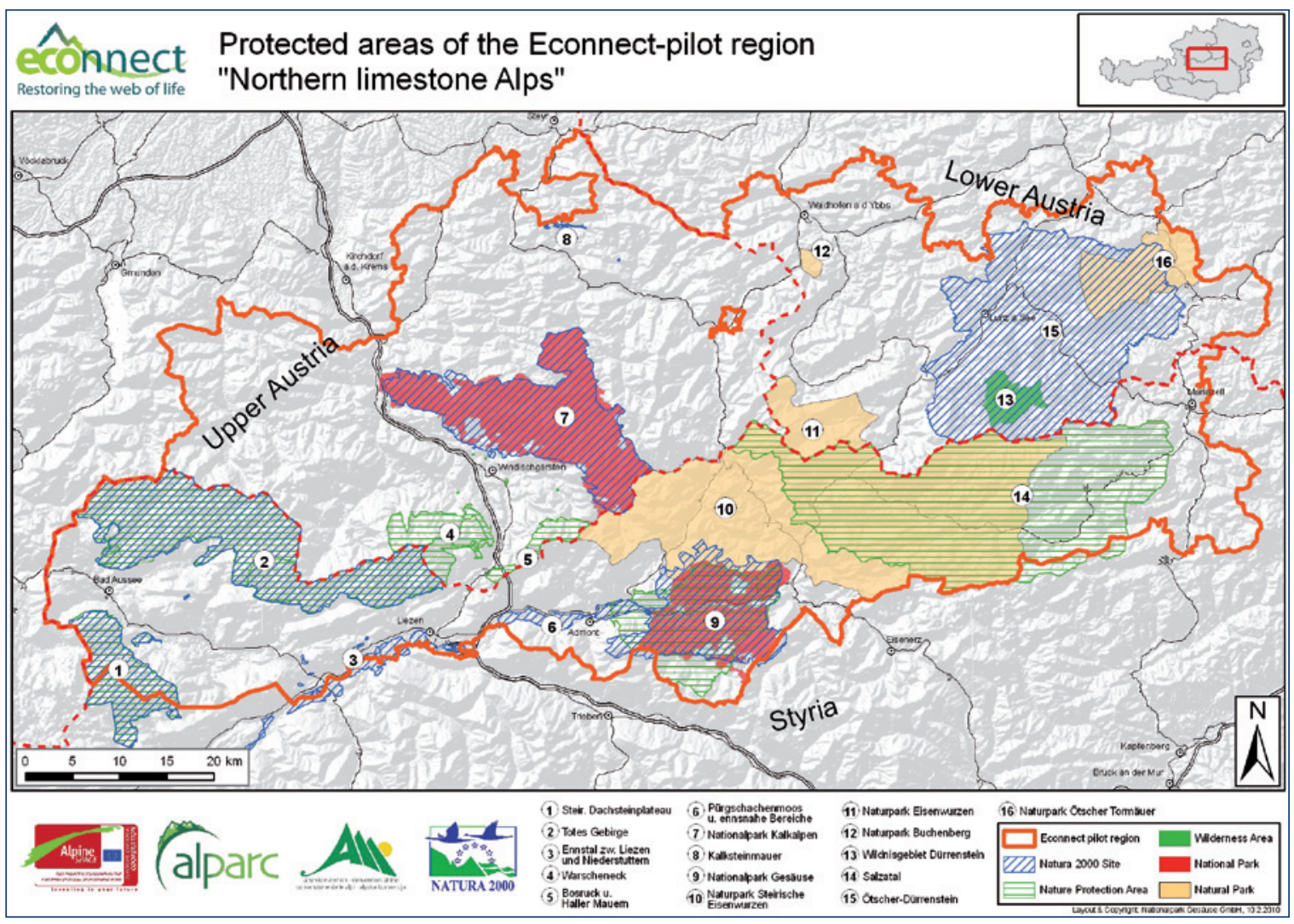

Figure 2 - Protected areas in the Northern Limestone Alps in the area where the provinces of Styria, Lower and Upper Austria meet. (C) Gesäuse NP

Upper Austria (Figure 2). From the earliest times of mountaineering, the Gesäuse has been popular with ramblers and mountaineers who appreciated its beautiful and challenging landscape.

\section{The Gesäuse - a diversity treasure trove}

Diversity is the dominant feature of the youngest Austrian national park. The river Enns provides the backbone of the Gesäuse NP. In the course of millions of years, it has cut deep into the mountains and created a gorge with a drop of up to $1800 \mathrm{~m}$ from the highest peaks to the valley floor. The Gesäuse holds the last unregulated sections of this great alpine river. Its thundering and swooshing noises (Sausen) gave the whole region its name "Gesäuse". Bodies of water and riparian forests along the rivers Enns and Johnsbach are a major feature of Gesäuse NP, even if they only make up about $1 \%$ of the total area.

Some $45 \%$ of the national park area is forest. The most common type of forest in terms of acreage is spruce with about $15 \%$. This means an urgent call for action to manage the forest stocks actively in an effort to recreate near-natural conditions. Subalpine coniferous forests, natural montane coniferous forests and beech forests (spruce/fir/beech forests) each cover about $10 \%$ of the total area. At $15 \%$, dwarf pine scrub (elfin woodland) is the most common natural habitat type. The dwarf beech woodland in avalanche chutes only makes up about $1 \%$ of the area but is a peculiarity of the Gesäuse. The largest dwarf beech stocks are found at the Tamischbachturm (Thum 2009) and cover an area of nearly 30 ha (Figure $3 \& 4$ ).

About a quarter of the area is made up of boulders and screes with little or no vegetation, typical for the high mountain character of the Ennstal Alps. The areas with the highest species diversity are the treeless alpine grasslands, the mountain pastures and avalanche chutes. Between them they take up about $11 \%$ of the total area. Avalanche chutes are considered hotspots of species diversity in the Gesäuse. In two avalanche chutes from the Tamischbachturm (Figure 5), 503 types of butterfly have been identified so far (Habeler 2009) as well as 77 species of fern and seed plants, the highest number of a single relevé (Bohner et al. 2009). $2 \%$ of the total area are clearings, settlement areas and transport routes (incl. forest roads). Along the valley, a rail track and a major road cut through the area, an ecological injury that has to be accepted as a given. Problems with noise, immissions and the necessary protection of the infrastructure are just some of the far-reaching consequences.

Great drops, varying inclinations and expositions as well as different limestone and graywacke soils allow species-rich biocoenoses. Highlights include nearnatural mixed forests, mountain meadows rich in insects and species adapted to rocky or wetland habitats. Within a research project focusing on near-natural forests, 146 types of lichen, 101 bryophytes and 50 
polypores were identified on dead wood, including a lignicolous fungus hitherto unknown in the Alps, Trichaptum laricinum. Rosalia longicorn (Rosalia alpina), a characteristic species of beech forests in sunny exposition was also found in several places (Figure 6).

Spring horizons are one of the monitoring foci in the national park. It is at springs that some completely new species hide, e.g. a new type of stonefly (Leuctra astridae) (Figure 7) and a new type of empididae (Hemerodromia strobli), named after the very active late $19^{\text {th }}$ century naturalist from the Benedictine monastery at Admont, Father Gabriel Strobl.

Numerous studies on the running waters of Enns and Johnsbach underline the uniqueness of these banks and gravel bars. 52 kinds of spiders and 66 kinds of ground beetles were identified here. Of the extremely rare species at near-natural running waters you can also find the common sandpiper (Actitis bypoleucos) and the Eurasian otter (Lutra lutra). Last century, Myricaria germanica had died out along the river Enns. Now efforts are under way to reintroduce the plant in the area (Figure 8 \& 9).

Botanical highlights include the rare wild pink Dianthus plumarius ssp. blandus (Figure 10), an endemic species only occurring between Grimming and the Ennstal Alps. A recent study has identified the Gesäuse as the Austrian endemite hotspot (Figure 11). The quadrant with the highest number of endemites, 70 animals and plants in total, is situated in the Gesäuse (Rabitsch \& Essl 2009). Most endemites have their habitat in the alpine zone. This is also the home of chamois (Rupicapra rupicapra), marmot (Marmota marmota), ptarmigan (Lagopus mutus) and golden eagle (Aquila chrysaetos), to name but the most striking species. Research has been done locally on many of these species (Hölscher 2005, Maurer 2007, Schmotzer 2007).

\section{Towards a national park}

In the 1980s, efforts started on the part of the Styrian province and from conservation and environmental groups to create a Styrian national park (Würflinger 2007). Following debates about a national park in the Niedere Tauern and Totes Gebirge ranges and about extending the Kalkalpen NP into Styrian territory, discussions eventually focused on the Gesäuse. They were also triggered by plans on the part of the Benedictine monastery in Admont to build a power station at the entrance to the Gesäuse gorge. In 1988, these plans were stopped by the designation of the so-called "entrance" to the Gesäuse as a natural monument. In 1996, planning for a national park was taken up by the Styrian provincial government.

A feasibility study commissioned in 1998 by the province of Styria and the Ministry of the Environment, Generations and Family, provided the substantive basis for planning the national park (Jungmeier et al. 1999). It identified good preconditions for establishing a national park in the Gesäuse and emphasized

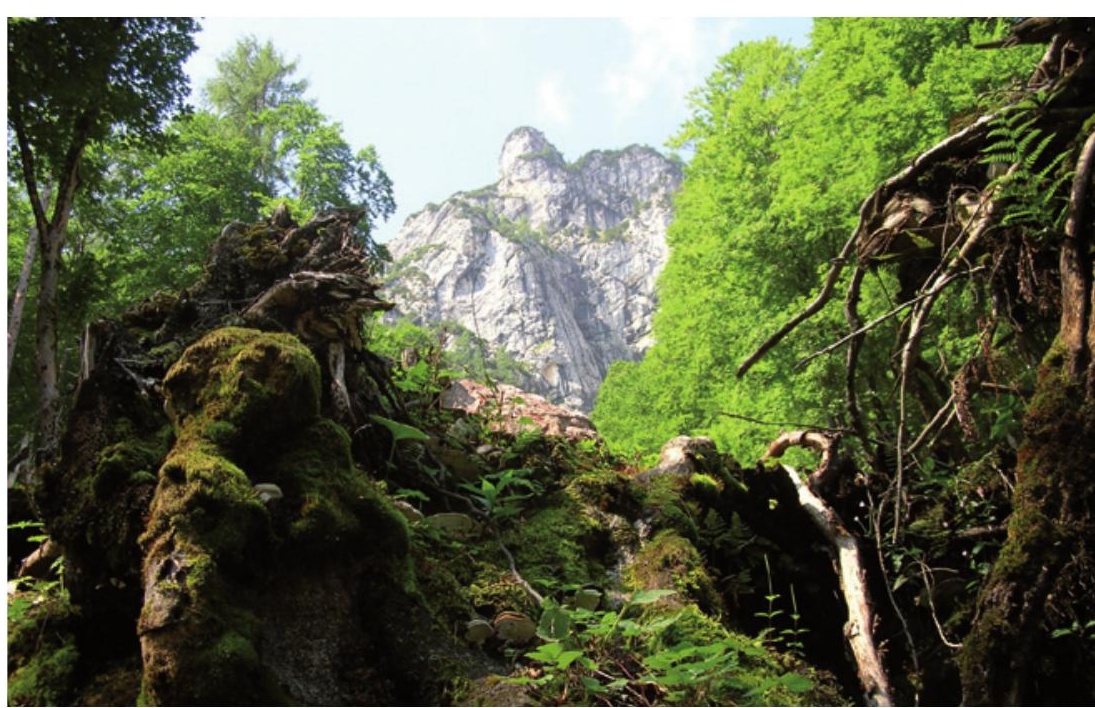

Figure 3 - Forests are the habitat type covering the largest area in Gesäuse NP, but virgin forests are rare. (C) Ch. Mairbuber

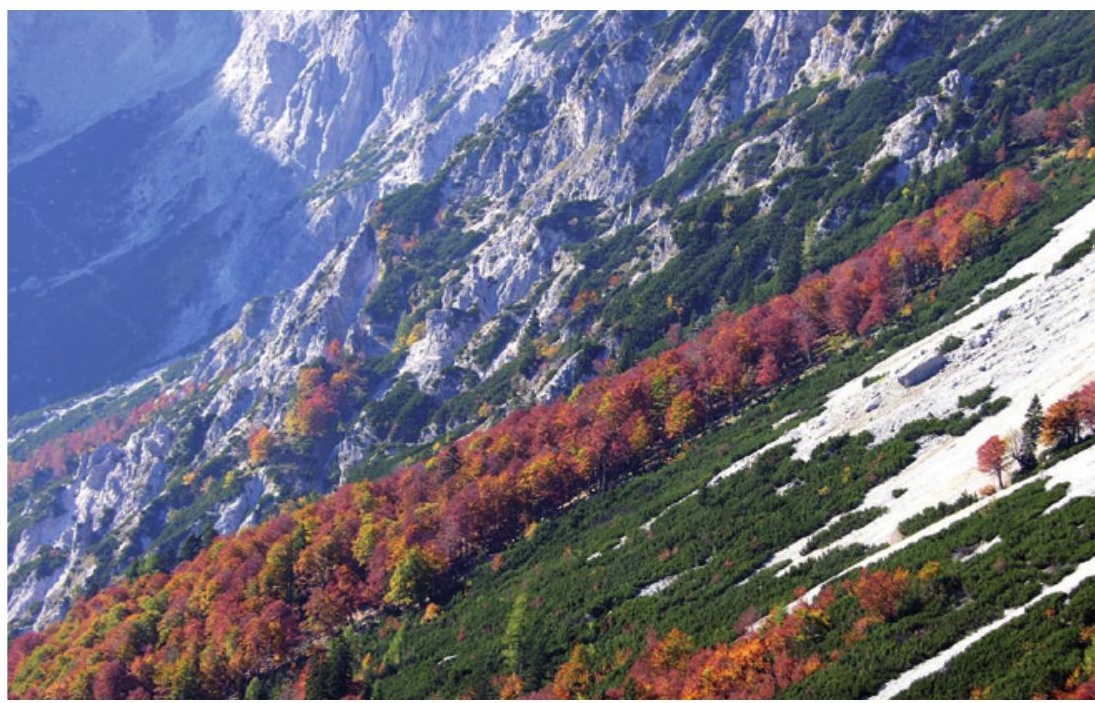

Figure $4-A$ mosaic of screes, dwarf pine scrub and beech forests, the high dynamics and the combination of different structures within a small space allow great biodiversity. (C) Nationalpark Gesäuse GmbH

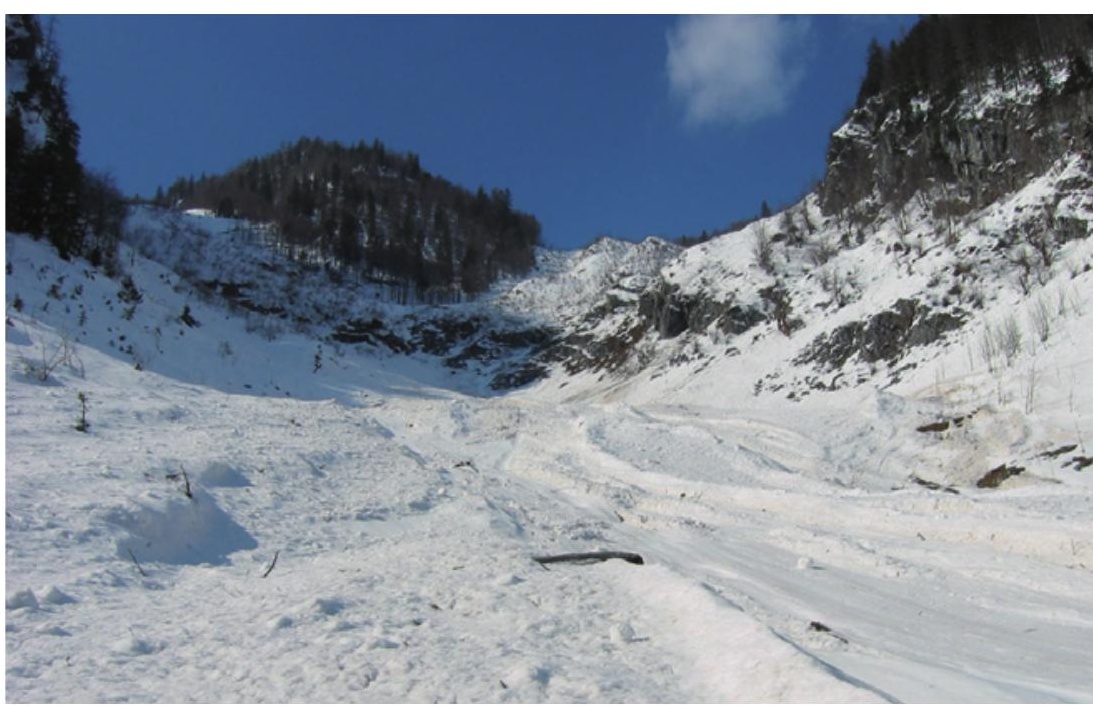

Figure 5 - The avalanche chutes at the Tamischbachturm are hotspots of species diversity in the Gesäuse. (C) R. Haslinger 


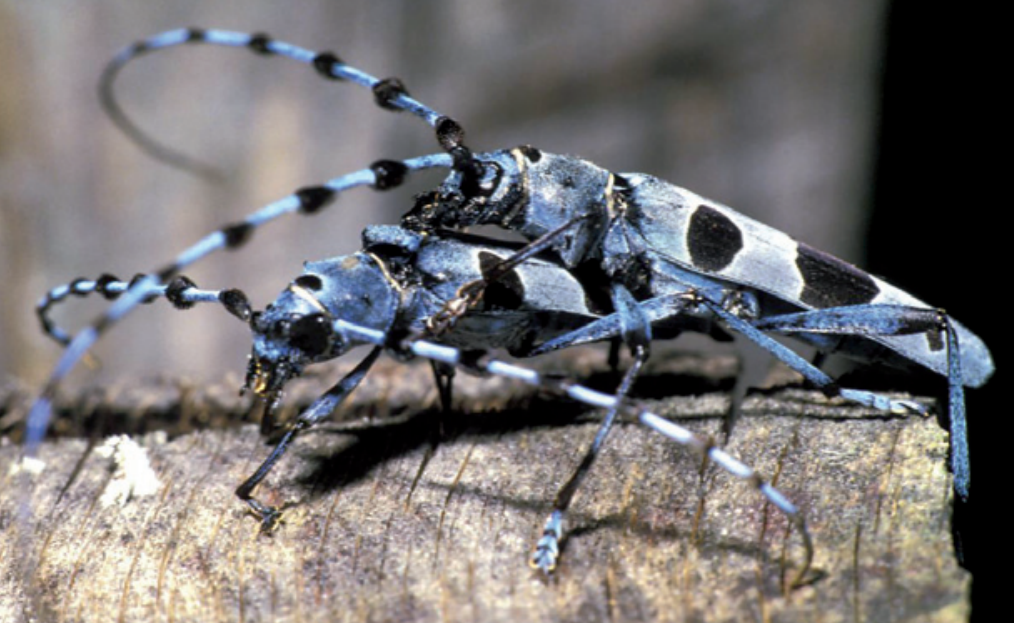

Figure 6 - Rosalia longicorn, an indicator of near-natural mixed beech woodlands. C H. Keil

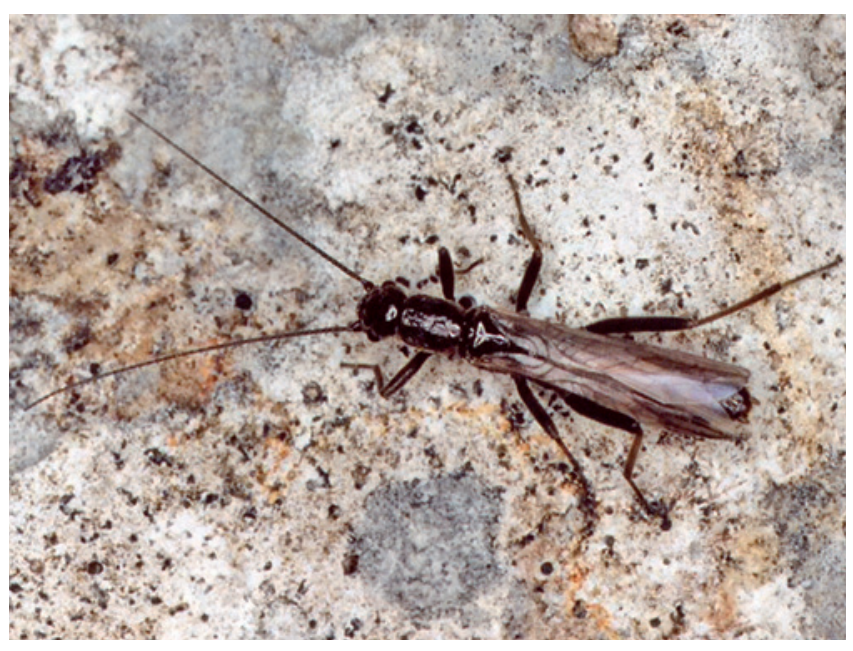

Figure 7 - A new type of stonefly (Leuctra astridae) from the national park. (C) A. Schmidt-Kloiber the special significance of the natural landscape, the likely effects on the regional economy and the ownership situation (mainly public ownership). Potential conflicts listed included underinformed and sceptical public opinion, the hunting community, forestry and utilization of raw materials. The short concrete planning phase should not be read as a sign of a harmonious implementation of the Gesäuse NP. It took six years of intense debates to reach the designation of the area as a national park. At the same time as the provincial government passed a resolution to establish the national park, a "Protection Association" formed to oppose the plans. A significant aspect in the successful implementation was the fact that almost the entire area was owned by the Styrian Provincial Forestry Commission (Steiermärkische Landesforste).

Six years later, on 26 October 2002, the Gesäuse NP was established. It is the Austrian national park with the shortest implementation time. Recognition by the IUCN as a Cat. II protected area followed in 2003.

\section{Managing the Gesäuse National Park}

The Nationalpark Gesäuse $\mathrm{GmbH}$ is funded by the Federal Ministry of Agriculture, Forestry, Environment and Water Management and by the federal province of Styria. The Steiermärkische Landesforste owns $99.3 \%$ of the area. The agreement between the federal authorities and the province of Styria under section $15 \mathrm{a}$ B-VG on the creation and operation of a Gesäuse NP (LGBl. Nr. 70/2003) and the Gesäuse NP Act (LGBl. Nr. 61/2002) and the regulations therein form the regulatory framework.

The Nationalpark Gesäuse GmbH is subdivided into the management and the secretary's office plus four departments: conservation and research, environmental education, national park presentation, woodland and deer management, as well as a staff position for PR and the travel agency. The office of the head of the department for woodland and deer management doubles up as the regional headquarter of the Steiermärkische Landesforste. Some ten employees of the Steiermärkische Landesforste carry out national park management

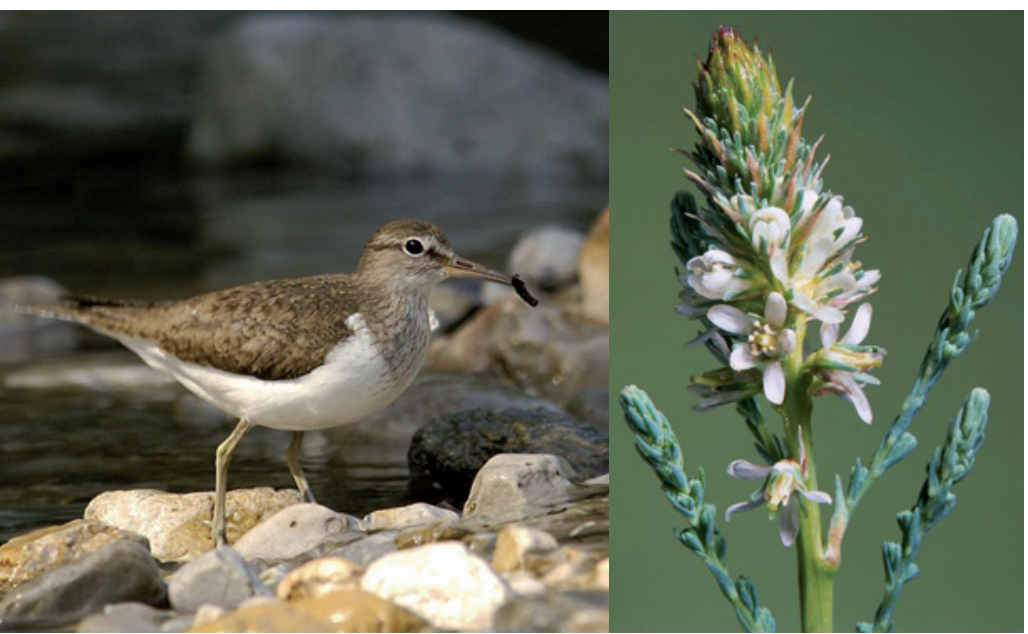

Figures 8 and 9 - Actitis hypoleucos and Myricaria germanica, two typical species at the banks of the Enns. (C) H. Marek and J. Pötscher

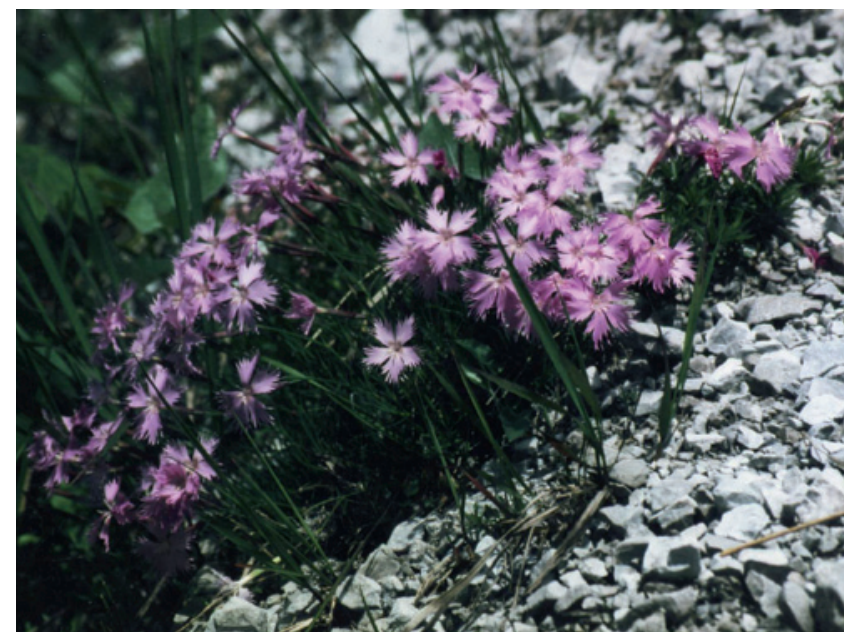

Figure 10 - The wild pink. Dianthus plumarius ssp. blandus is endemic in the Gesäuse. (C) J. Greimler 


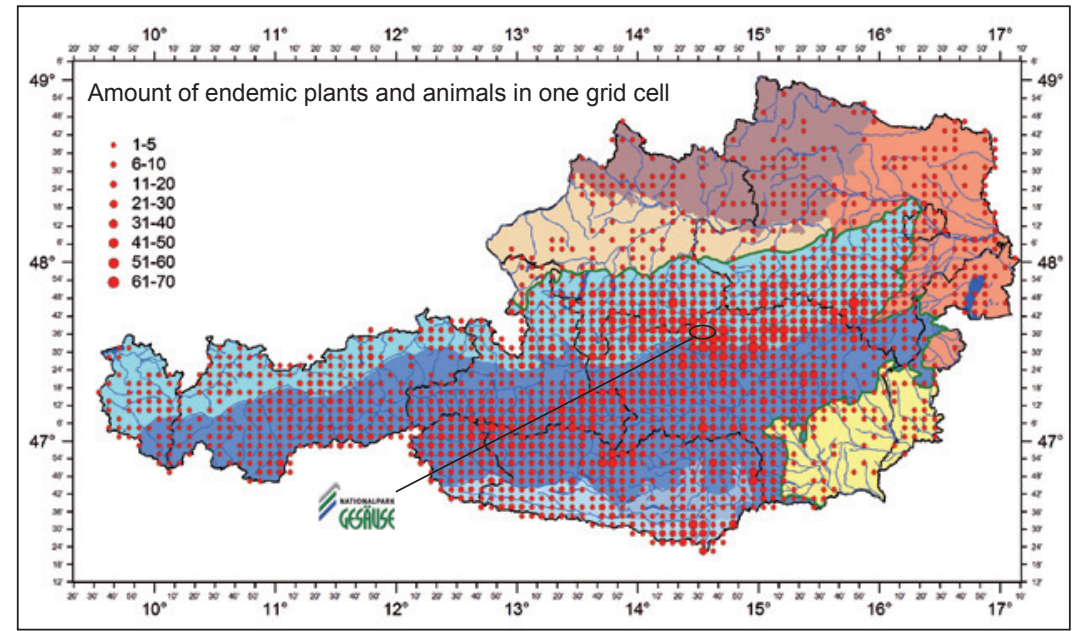

Figure 11 - Gesäuse NP is the Austrian endemite hotspot. (C) UBA 2009 and biodiversity. It also demonstrates the positive interaction of nature and culture, man and environment.

The EU Alpine Space project "ECONNECT - networking habitats, connecting people" (Figure 12) creates opportunities for synergies and cooperations between stakeholders such as protected areas, agriculture and forestry, hunters, fishers and tourism with the joint aim to preserve the varied flora and fauna. In the long term, the project aims to ensure that there are sufficient habitats for various endangered species and

tasks. 40 independent rangers provide guided tours and 60 Styrian NP volunteers patrol the area.

Below is a summary of the four major tasks of the Gesäuse NP: conservation, recreation, education on nature and conservation, and research.

\section{Conservation}

The area of the national park is made up of a core zone and a managed land-use zone.

$86 \%$ of the area is designated as core zone, where the protection of the natural habitats is paramount. The long-term objective for this zone is for natural processes to be left to take their course without human intervention. Initially, however, some regulating interventions are necessary here too, for instance, transforming spruce forests into near-natural mixed woodland.

The managed land-use zone on the remaining $14 \%$ of the total national park area mainly serves to maintain the cultural landscape. As the high mountain pastures in the national park show, this enriches both scenery that migration corridors between them are maintained or newly created (see also Figure 2).

The LIFE project "Conservation strategies for woodland and wild waters in the Gesäuse" was started in 2005 and runs until 2010 (Figure 13). It aims to carry out conservation measures for endangered species and habitats as defined by the NATURA 2000 concept. To this end it collaborates with the Steiermärkische Landesforste, the Austrian Service for Torrent and Avalanche Control and the Styrian flood control department. The conservation measures are quite diverse and apply to beech forests as much as to the lady's slipper (Cypripedium calceolus), the Ukrainian brook lamprey (Eudontomyzon vladykovi) or the capercaillie (Tetrao urogallus). The project supports measures as diverse as transforming spruce forests into mixed woodland, managing high mountain pastures and conservation measures along the rivers Enns and Johnsbach. The water projects are renaturation measures on severely regulated and controlled sections of the water bodies. They should protect the infrastructure while increasing the flood dynamics in the contiguous national park areas. Many

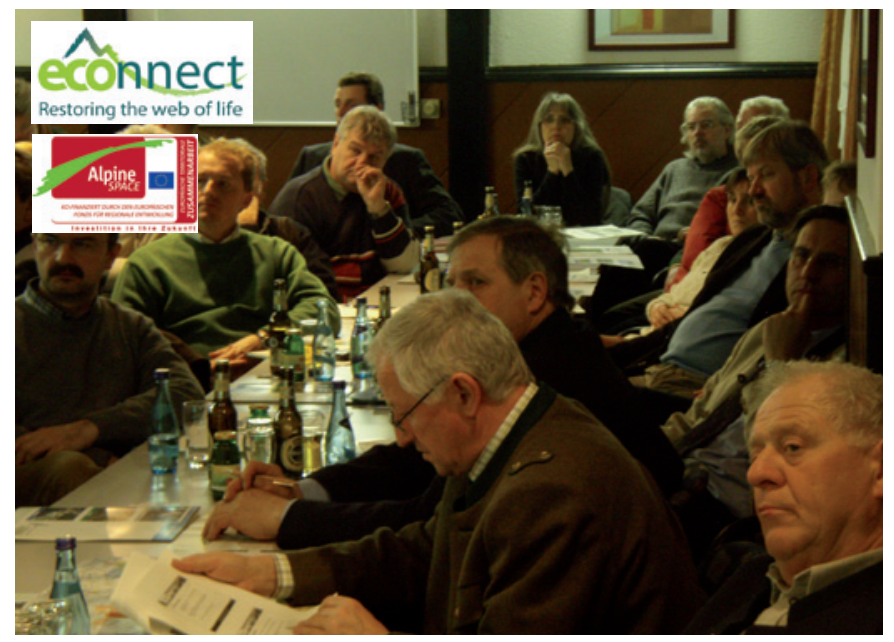

Figure 12 - Working group meeting within the ECONNECT project. (C) D. Kreiner

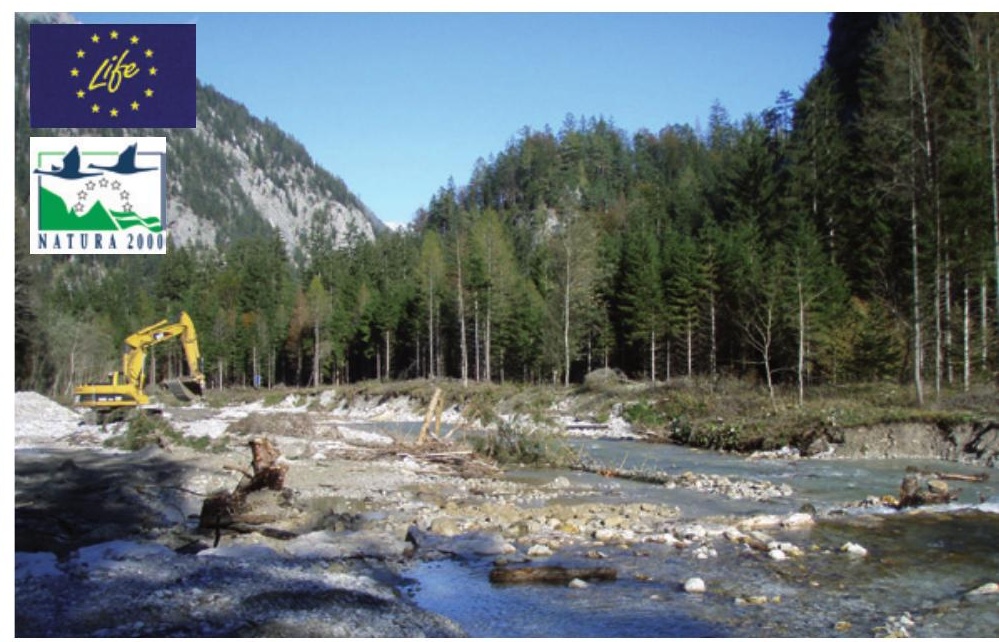

Figure 13 - LIFE renaturation site at Johnsbach. (C) D. Kreiner 
specialized animals that depend on floods, such as certain ground beetles and spiders, will also benefit from these measures.

\section{Recreation}

For 200 years the Gesäuse has been popular with ramblers, mountaineers and climbers. The national park aims to provide visitors with high-quality recreation while protecting the flora and fauna. Positive visitor management makes the visitors aware of the natural environment in the Gesäuse NP and lets them experience the Gesäuse. At the same time, it should protect sensitive areas and prevent negative impacts on animal and plant species. Following the "honeypot strategy", many attractions are concentrated along the valley floor, where the main road runs parallel to the river Enns. This is where the NP Pavilion is situated, which houses a geological exhibition. Further on in the same valley is the "Willow Dome Experience Centre" ( $\mathrm{Na}$ tionalpark Erlebniszentrum Weidendom), where several themed walks start.

The visitor management concept of the national park (Zechner 2009) regulates the totality of possible tourist and recreational activities in terms of their impact on habitats and plant and animal species. It was designed in cooperation with the land owners and with local experts and focuses on indirect ways of controlling visitor flows. There are two main areas where uncontrolled utilization can have a negative impact on flora and fauna. These are the water habitats along Enns and Johnsbach and two back country skiing routes in Johnsbach.

Three visitor areas were created along the river Enns and its largest tributary within the park, the Johnsbach. They are used to manage visitors at the water's edge in the sensitive water habitats. Leaflets and signposts carry information on environmentally sound behaviour, landing places for boats, visitor areas and the public barbecue area on the camp site in Gstatterboden. From May till October, national park staff is patrolling the water bodies mainly at weekends and during school holidays to inform and caution visitors as needed. Commercial use of the river Enns for rafting is allowed for licensed rafting companies and limited to certain times.

Two ski routes in the Johnsbach valley needed to be partly relocated so as not to impair the winter habitats of capercaillie and black grouse. A leaflet on ski tours explains the redesigned uphill and downhill routes and includes tips on environmentally sound behaviour in winter. On the ground, the ski routes are regularly cut free and sign-posted throughout, with regular patrols of national park orderlies another important element. They prepare the skiing track after snowfall, provide the first point of call for the visitors in situ and oversee compliance with the national park act.

In the course of creating the visitor management concept visitors were also monitored (Arnberger et al. 2009). Hiking, walking and ski tours (Figure 14 \& 15) are the most common leisure activities in the area. Top reasons given for visiting were experiencing nature, relaxation, recreation and quiet. The visitors are very content with the Gesäuse as recreational space and $75 \%$ of them regard visitor numbers as pleasant. For visitors, the main tasks of a national park are protecting rare animals and plants and their habitats, preserving and recreating near-natural landscapes and at the same time providing high-quality recreation. The majority of visitors accepts limitations on recreational use in habitats of rare or protected animals.

\section{Education}

One major task of a national park is providing information on dynamics in nature in suitable formats for

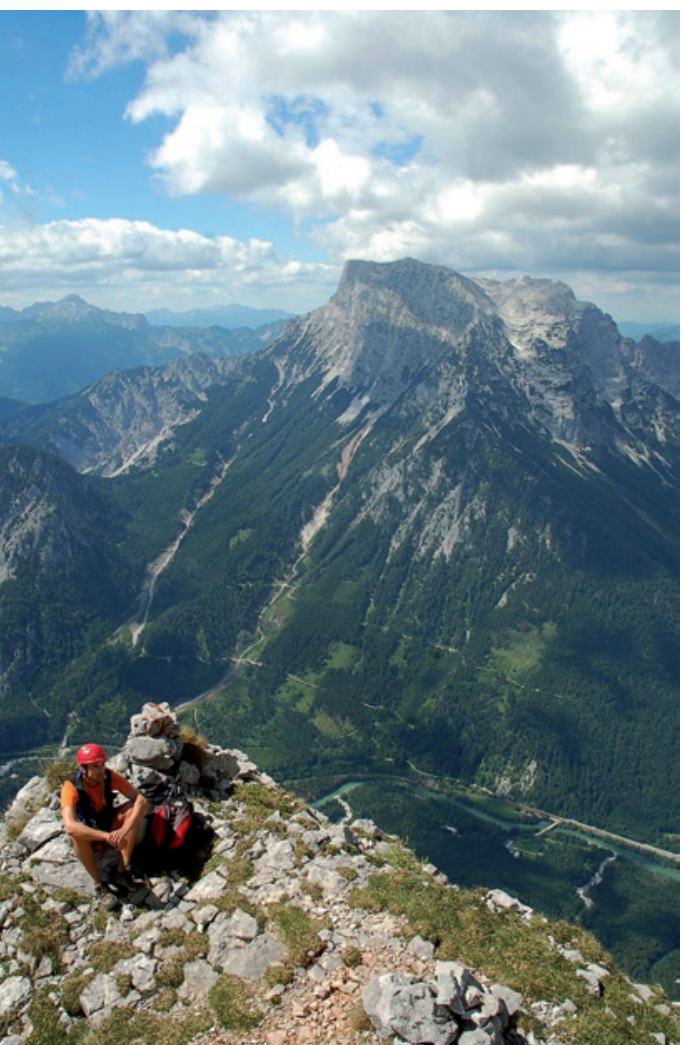

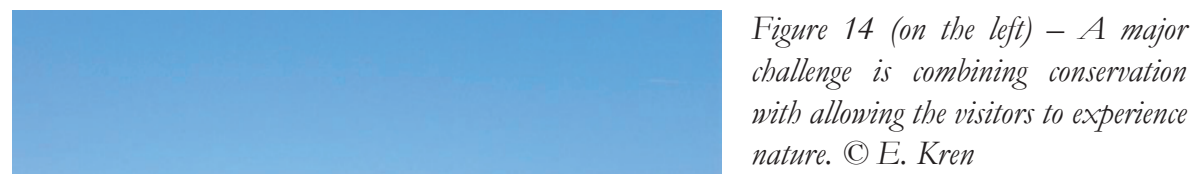

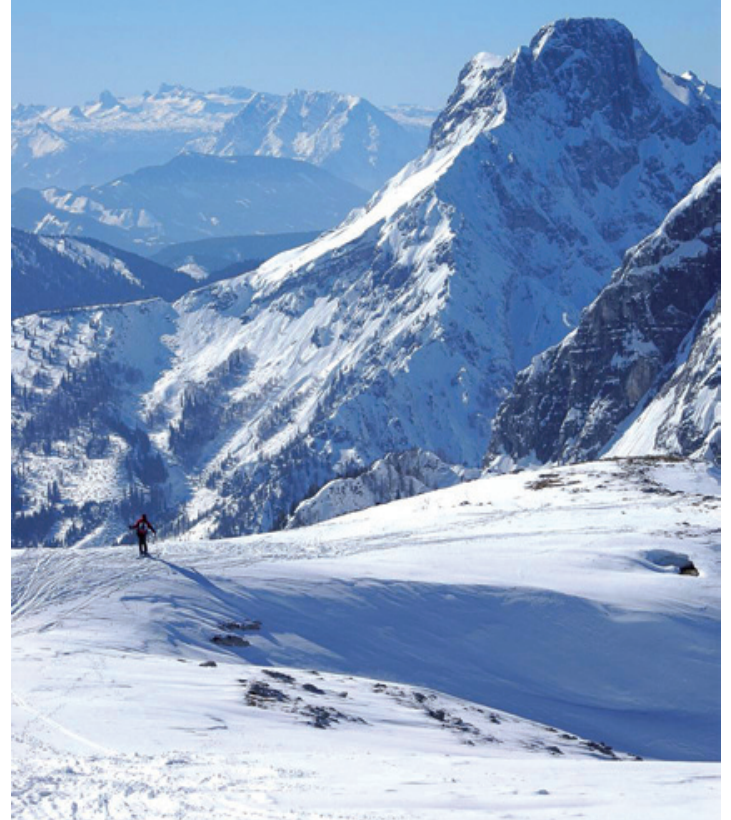

Figure 15 (on the right) - The Johnsbachtal is particularly popular with ski tour enthusiasts. (C) E. Kren 
different target audiences and different levels of background knowledge. This ranges from packages for nursery and primary schools to educating adults and special excursions for experts. The motto for education work at Gesäuse NP is "You only love what you know and you only protect what you love".

Visitors experience the national park through a varied all-year programme. Annual events and festivities like pre-Christmas activities in the Weidendom also appeal to the local population.

There are two permanent de-centralized visitor centres along the valley floor of the national park: the NP Experience Centre in the Weidendom and the NP Pavilion (Figure 16 \& 17).

The Weidendom in the Gesäuse NP is one of the largest living tree monuments in the Alps. Here, visitors can get information on the national park, participate in a research programme on the theme of water and soil or enjoy the magnificent panorama.

For the coming years there are plans to expand the Weidendom with a "walk-in ecological footprint" to impress on the visitors the significance, effects and options of individual agency.

The themed walk through the Lettmair Au with its interactive stations offers insights into the ecology of a riparian woodland. Another themed walk for all the family is the "path of legends" (Sagenweg) currently being replanned. It will run along the renaturalized Johnsbach and recount the newly created legend of Giant John, who was in chains and is freed eventually. The legend serves to explain the previous severe water engineering measures and the importance of cooperation between water ecology and torrent control.

The NP Pavilion in Gstatterboden offers views of the rock slides of the Hochtor range, the most striking group of peaks in the Gesäuse NP. It includes a cafeteria and an interactive geological exhibition where visitors travel back in time to when the Gesäuse landscape developed. Virtual national park ranger Sepp is their entertaining guide through the tasks visitors have to fulfil in the course of their geological discoveries (Figure 17).

There is a modular package for schools which can be booked through the national park travel agency. It provides programmes for schools ranging from half a day to a whole week. Since 2007, all teachers are asked to fill in a standardized questionnaire after their project day(s) in the Gesäuse NP. Almost $95 \%$ of the teachers have declared themselves (very) satisfied with their stay in the national park (Sterl 2009).

In the decade "Education for sustainable development", the UNESCO chose two of the educational projects of the Gesäuse NP as projects of the decade: the Junior Ranger Project and the Gesäuse NP Primary School Hieflau.

The Junior Ranger Project aims to involve children and teenagers from the region in the varied tasks and activities of the national park. Getting to know about the natural and cultural landscape of the national park

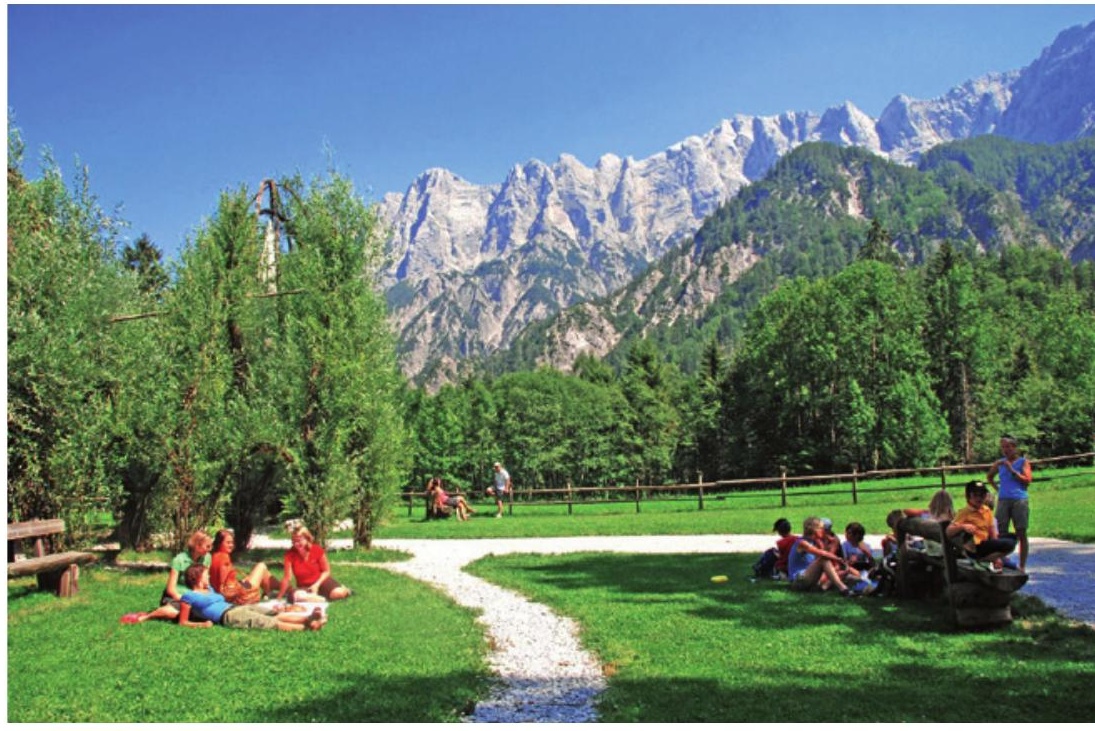

Figure 16 - Visitors to the Weidendom enjoying the view. (C) E. Kren

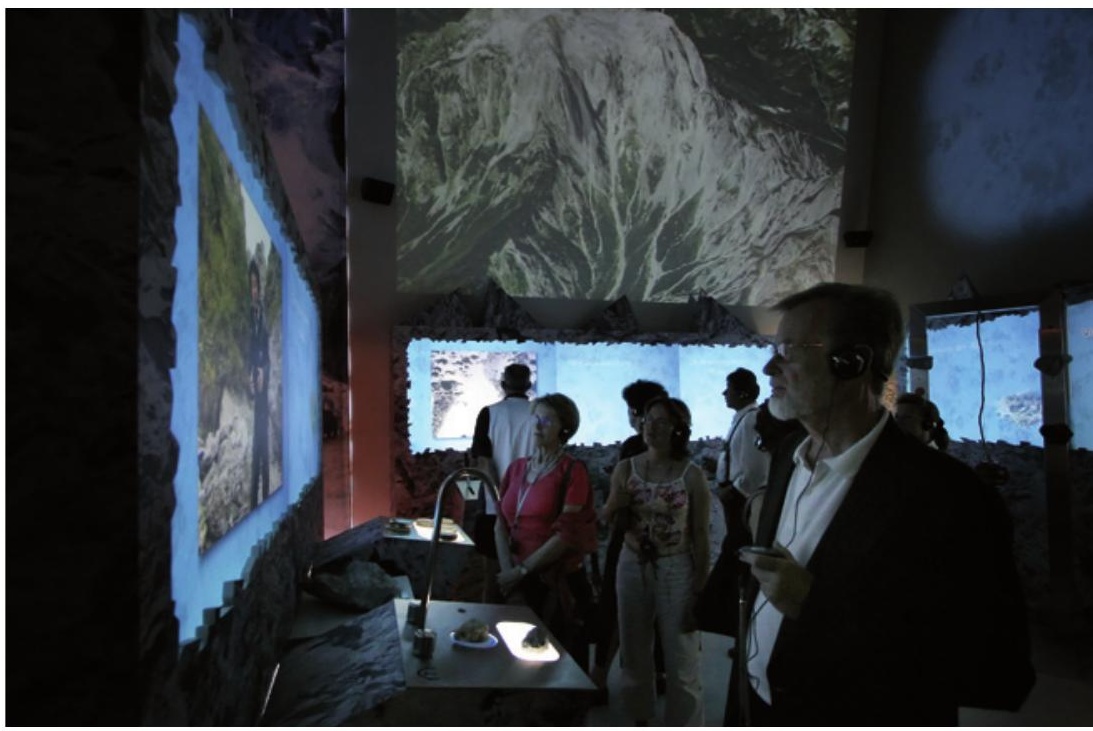

Figure 17 - The interactive geological exhibition encourages visitors to get involved. (C) C. Fürnholzer

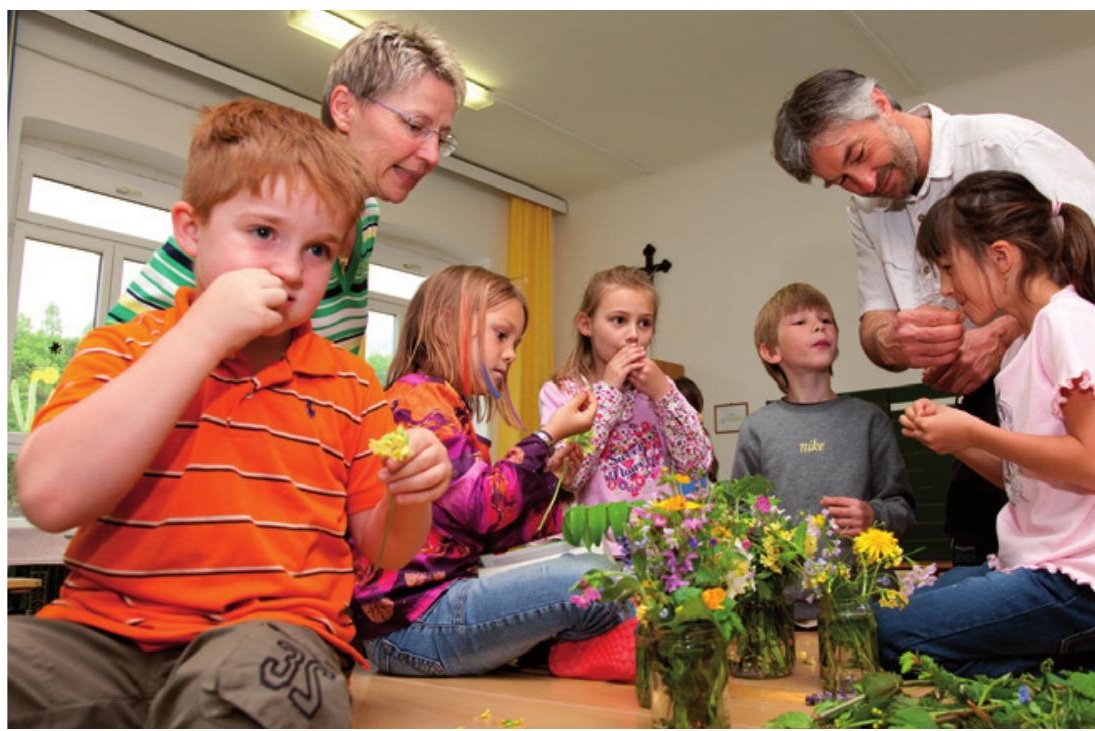

Figure 18 - A national park ranger identifies plants with a Hieflau primary school class. (C) C. Fürnholzer 


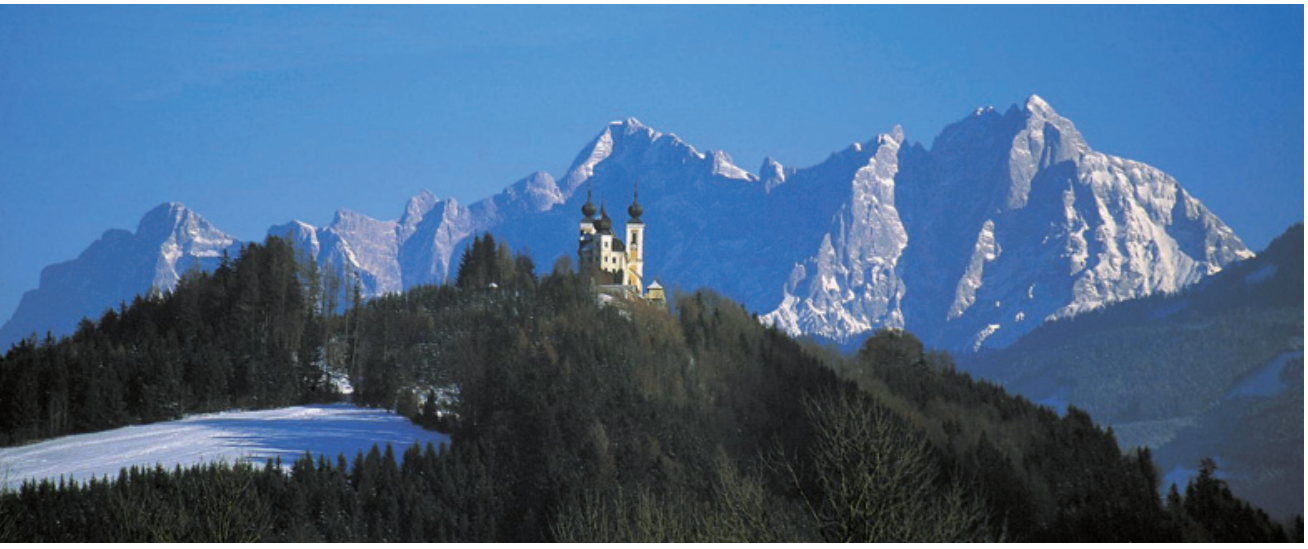

permanent monitoring sites in diverse habitats (springs, running waters, forest, high mountain pastures, peaks, etc.). In addition to monitoring the vegetation in these sites, the focus is on identifying various groups of animals as indicator species. These special climate change monitoring projects in the national park include studies of flora and fauna at peaks and the creation of a network of metereological measuring stations that represents all altitudinal zones and expositions.

Frauenberg church against the Hochtor range. (C) E. Kren

A project modelling climate and hydrological scenarios is headed by the Uni-

region is the basis for treating it in a responsible way. The project Gesäuse NP Primary School has similar aims. The primary school works closely with the national park to present the concept of the national park attractively to pupils and their parents. Every year has its special theme, which features in the classes as well as in the national park in a variety of aspects and is accompanied by a park ranger. The pupils gain an understanding of the conservation concept through the close involvement of the national park and national park content in the curriculum (Figure 18).

In future, visitors will be offered information across space and time by the digital tour guide Xeisguide. In this way the national park aims to address visitors who do not use its traditional information channels.

Since its foundation, the number of visitors directly looked after by the national park has risen constantly. Specially trained rangers and external experts ensure the quality of the environmental education programmes. Each year the national park rangers take advantage of continued professional development events on natural science and educational methods. Project days of schools have been evaluated since 2007 as a matter of course. From 2010, the events and project in the Weidendom and the geological exhibition as well as the events of the annual programme will be evaluated by participants.

\section{Research}

Research in the Gesäuse NP concentrates in implementing its core tasks of protecting habitats and species. Most of it is therefore research into applied conservation, with basic research taking second place. Applied conservation research includes documenting habitats and species in the national park, basic research includes long-term research and monitoring of changes in the natural landscape.

In the Gesäuse NP the focus is on dynamic habitats like avalanche chutes, windthrow areas, scree gullies or gravel banks in the river. Initial results underline the special significance of these ecosystems shaped by extreme weather for biodiversity in the national park.

In terms of long-term research, over the last seven years the Gesäuse NP has established a network of versity of Graz and includes a dozen partners. The national park works closely with universities on numerous projects. Many theses have been written on issues of the Gesäuse. The national park offers the local infrastructure and the universities bring their special know-how to the research in the national park.

The research platform Eisenwurzen emerged from a cooperation with other research institutions in the vicinity. It aims to carry out joint socio-ecological longterm research on regional issues and to look for new solutions. Embedded in an international research environment, all partners (regional stakeholders, protected areas, Environment Agency Austria, EU, universities, etc.) work towards a successful research cooperation (http://www.umweltbundesamt.at/mfrp_eisenwurzen/).

All research deliverables in the national park are also available online on the dedicated research web page http://www.nationalpark.co.at/nationalpark/de/forschung.php.

It provides current weather data from the climate stations in the national park as well as hourly updated webcam views from the Johnsbachtal. The publication series of the Gesäuse NP disseminates the research results annually in analogue format. For further information see http://www.nationalpark.co.at/nationalpark/de/shop-buecher.php.

\section{The national park and its economic envi- ronment}

The region is marketed as a nature tourism destination in cooperation with the tourist association Alpenregion Nationalpark Gesäuse. The theme of culture and nature combines the attractions of the famous Benedictine monastery at Admont, the Nature Park Steirische Eisenwurzen and the Gesäuse NP. The Gesäuse NP and the tourist association Alpenregion Nationalpark Gesäuse jointly run an information office at Admont. In 2009, the Gesäuse NP, in cooperation with the tourist association, reached second place at the Eden Award. With this award the European Commission recognizes tourist destinations that use their region as a tourist destination in a sustainable manner. 
As part of a national park partner project, a network of companies in the region was created. These companies work closely with each other and with the national park towards the common aim of strengthening the economy of the region and leveraging it to boost tourism. Their motto "regional - ecological - creative" is to strengthen quality and ecological awareness in the participating businesses and help with joint marketing. One example of this cooperation is the creation of the label Genussregion Gesäuse Wild (region of venison specialities), which was started up by the partner companies of the national park. Results of a visitor survey in the summer of 2007/08 showed that for a third of the visitors the national park played an important or very important role in their decision to visit the region (Arnberger et al. 2009). Nearly $8 \%$ of those interviewed may be called fans of the national park, some $26 \%$ are visitors interested in the national park. Tourists who specifically visited the national park appreciate its benefits and are mainly interested in nature. They also spend the most in the region. Visitors interested in the national park focus on recreation and activities such as walking and climbing. The largest group is that of visitors to the Gesäuse whose decision is not influenced by the existence of the national park.

\section{Evaluation}

Evaluating the Gesäuse NP is a legal requirement (LGBl. No. 15/2003, Section 15). The Nationalpark Gesäuse $\mathrm{GmbH}$ commissioned an evaluation complying with international standards and involving stakeholders, which was carried out from November 2007 to May 2008 (Getzner et al. 2008). The evaluators analysed documents, talked to stakeholders, held regional workshops and carried a model calculation of the economic effects on the region. On this basis they came to a positive conclusion on the overall picture of the Gesäuse NP.

Individual aspects that were considered particularly successful (Getzner et al. 2008):

- innovative and high-quality, sometimes unique provision of infrastructure and events for visitors generally and in educational programmes;

- broad and systematic PR in the region and beyond; well-qualified, motivated and effective team in a modern service provider;

- natural resources inventory, quality of selected research and planning instruments (e.g. visitor management);

- (first) proven positive effects on the regional economy.

Individual aspects with room for improvement:

- reducing the barrier effect of roads, rail tracks, forest and access roads (e.g. to mountain pastures);

consolidating the budget situation through adjusting the value of the partner contributions (the current financial situation is only secured until 2012); continued development of the legal framework for a strict application of the IUCN criteria.

The evaluation pointed out urgent need for action in the following aspects:

increased involvement and participation options for stakeholders and affected parties within and beyond the region - creation of a consultative committee;

creation of a comprehensive management plan (vision, aims, implementation) with stakeholders;

improving the coordination between land owner (Steiermärkische Landesforste) and the Nationalpark Gesäuse GmbH;

- improving delimitation and zoning and formulating a perspective for the further development of the natural resources of the national park.

The evaluation report can be called up in full from the website of the Gesäuse NP (www.nationalpark.co.at).

\section{Infobox}

\section{Gesäuse National Park}

Total area: 11054 ha

Core zone: $86 \%$

Managed land-use zone: $14 \%$

Established: 26 October 2002

International recognition by the IUCN: 5 December 2003

\section{Natural landscape}

\section{Forest: $48 \%$}

Dwarf pine scrub (elfin woodland): $16 \%$

Avalanche scrub: $1 \%$

Rock (rock and scree communities of plants): $25 \%$

Alpine meadows: $7 \%$

High mountain pasture: $2 \%$

Bodies of water: $0.5 \%$

Infrastructure, roads: $0.5 \%$

Ownership:

99.3\% Styrian Provincial Forestry Commission (Steiermärkische Landesforste) $0.5 \%$ public water bodies

$0.2 \%$ private owners

National park municipalities and their share of the national park area:

Johnsbach $51 \%$, Weng 30\%, Admont 7\%, Landl 6.5\%, Hieflau 4.5\%,

St. Gallen $1 \%$

\section{Visitor centres:}

Information office Admont: tourist information and national park information point: open all year

Geological exhibition in the National Park Pavilion in Gstatterboden: open May - October

National Park Experience Centre in the Weidendom (between Admont and

Hieflau, at the exit to Johnsbach): open May - September

Contact:

info@nationalpark.co.at - www.nationalpark.co.at 


\section{Prospects}

The Gesäuse NP team is taking on these tasks and the big responsibility. Recognition as IUCN Cat. II national park requires the efficient implementation of the four main tasks of the national park. The large number of endemic and endangered species, in combination with the very frequent dynamic natural processes makes the Gesäuse NP a core conservation area, integrated into a wonderful natural landscape in the heart of Austria. The educational projects offered in the national park meet contemporary requirements and stress the importance of individual agency for conservation and environmental protection. Cooperation within the region is creating an outstanding experience of nature and culture in the Gesäuse that can hold its own within Europe.

\section{References}

Arnberger, A., B. Allex \& R. Eder 2009. Besuchermonitoring im Nationalpark Gesäuse. Studie im Auftrag der Nationalpark Gesäuse GmbH. Available at: www. nationalpark.co.at

Bohner, A., H. Habeler, F. Starlinger \& M. Suanjak 2009. Vegetation \& Pflanzenartenvielfalt auf Lawinenbahnen der Südostseite des Tamischbachturmes. In: Kreiner, D. \& L. Zechner (eds.), Der Tamischbachturm. Schriften des Nationalparks Gesäuse. Band 4: 32-26.

Jungmeier, M. \& I. Velik 1999. Machbarkeitsstudie Nationalpark Gesäuse. Studie im Auftrag des Landes Steiermark und des Ministeriums für Umwelt, Jugend und Familie.

Getzner, M., M. Jungmeier, B. Pfleger \& W. Scherzinger 2008. Evaluierung Nationalpark. Gesäuse. Studie im Auftrag der Nationalpark Gesäuse GmbH. Available at: www.nationalpark.co.at

Habeler, H. 2009. Schmetterlinge in den Lawinenrinnen des Tamischbachturmes. In: Kreiner, D. \& L. Zechner (eds.), Der Tamischbachturm. Schriften des Nationalparkes Gesäuse. Band 4: 50-69.

Hölscher, S. 2005. Vergleichende Ökosystemanalyse mit GIS am Beispiel zweier alpiner Lebensräume des Steinadlers. Unveröffentlichte Studie im Auftrag der Nationalpark Gesäuse $\mathrm{GmbH}$.

Maurer, B. 2007. Sommerliche Habitatnutzung des Alpenschneehuhns (Lagopus mutus helveticus) am Zinödl (Nationalpark Gesäuse). Diplomarbeit Karl-FranzensUniversität Graz.

Rabitsch, W. \& F. Essl 2009. Endemiten: Kostbarkeiten in Österreichs Pflanzen- und Tierwelt. Naturwissenschaftlicher Verein für Kärnten und Umweltbundesamt $\mathrm{GmbH}$.

Schmotzer, I. 2007. Die Zukunftschancen des Alpenmurmeltierbestandes (Marmota marmota) im Nationalpark Gesäuse. Diplomarbeit Universität für Bodenkultur. Available at: www.nationalpark.co.at
Sterl, P. 2009. Befragung der Lebrerinnen und Lehrer 2007-2009. Unveröffentlichter Bericht des Nationalparks Gesäuse.

Thum, J. 2009. Der Legbuchenwald in der Kalktallawine bei Hieflau. In: Kreiner, D. \& L. Zechner (eds.). Der Tamischbachturm. Schriften des Nationalparks Gesäuse. Band 4: 24-31.

Würflinger, R. 2007. „Kultur statt verwilderte Natur" - Der Widerstand gegen die Errichtung des Nationalparks Gesäuse. Eine historische Diskursanalyse als Beitrag zur Umweltgeschichte Österreichs. Diplomarbeit an der Universität Wien. Available at: www.nationalpark.co.at

Zechner, L. 2009. Besucherlenkungskonzept Nationalpark Gesäuse. Unveröffentlichter Bericht des Nationalparks Gesäuse.

LGB1. Nr. 15/2003: Verordnung der Steiermärkischen Landesregierung vom 24. Februar 2003 über die Erklärung von Gebieten des Gesäuses zum Nationalpark, \} 1 5 .

\section{Authors}

Petra Sterl

Born 1978. Degree in landscape planning (University of Natural Resources and Applied Life Sciences, Vienna). Ranger at the Donau-Auen National Park. Research assistant at the University of Natural Resources and Applied Life Sciences. Environmental Education Officer at the Gesäuse NP since 2006.

petra.sterl@nationalpark.co.at

\section{Daniel Kreiner}

Born 1972. Degree in botany (University Graz) and geographical information science and systems (University Salzburg). Works on habitat mapping and evaluation of nature conservation value, GIS mapping and modelling, since 2003 employed at the Gesäuse $\mathrm{NP}$, responsible for nature conservation matters and research. Project leader of the LIFE Nature project "Conservation strategies for woodlands and rivers in the Gesäuse Mountains”.

daniel.kreiner@nationalpark.co.at

Gesäuse National Park

Weng 2, 8913 Weng/Gesäuse, Austria

Tel.: +43/3613/21000-24 